\title{
DID HUMANKIND PREVENT A HOLOCENE GLACIATION?
}

\author{
Comment on Ruddiman's Hypothesis of a Pre-Historic \\ Anthropocene \\ MARTIN CLAUSSEN ${ }^{1,2}$, VICTOR BROVKIN ${ }^{1}$, REINHARD CALOV $^{1}$, \\ ANDREY GANOPOLSKI ${ }^{1}$ and CLAUDIA KUBATZKI ${ }^{1}$ \\ ${ }^{1}$ Potsdam Institute for Climate Impact Research, P.O. Box 601203, 14412 Potsdam, Germany \\ ${ }^{2}$ Institute of Physics, Potsdam University, P.O. Box 601543, 14415 Potsdam, Germany
}

\begin{abstract}
Recently, W.F. Ruddiman (2003, Climatic Change, Vol. 61, pp. 261-293) suggested that the anthropocene, the geological epoch of significant anthropospheric interference with the natural Earth system, has started much earlier than previously thought (P. I. Crutzen and E. F. Stoermer, 2000, IGBP Newsletter, Vol. 429, pp. 623-628). Ruddiman proposed that due to human land use, atmospheric concentrations of $\mathrm{CO}_{2}$ and $\mathrm{CH}_{4}$ began to deviate from their natural declining trends some 8000 and 5000 years ago, respectively. Furthermore, Ruddiman concluded that greenhouse gas concentrations grew anomalously thereby preventing natural large-scale glaciation of northern North America that should have occurred some 4000-5000 years ago without human interference. Here we would like to comment on (a) natural changes in atmospheric $\mathrm{CO}_{2}$ concentration during the Holocene and (b) on the possibility of a Holocene glacial inception. We substantiate our comments by modelling results which suggest that the last three interglacials are not a proper analogue for Holocene climate variations. In particular, we show that our model does not yield a glacial inception during the last several thousand years even if a declining trend in atmospheric $\mathrm{CO}_{2}$ was assumed.
\end{abstract}

\section{Holocene $\mathrm{CO}_{2}$ Growth: No Need for Anthropogenic Forcing}

Ruddiman's interesting and thought-provoking idea of an early, global-scale effect of land use on climate is based on the assumption that the increase in atmospheric $\mathrm{CO}_{2}$ concentrations during the Holocene was anomalous with respect to trends reconstructed for the previous three interglacials. To corroborate his assumption, Ruddiman critically reassessed a number of mechanisms which have been proposed to explain the observed Holocene trend in atmospheric $\mathrm{CO}_{2}$ : changes in terrestrial biomass, changes in oceanic carbon compensation, and changes in ocean temperature and re-growth of coral reefs.

With respect to natural land cover changes as a cause for Holocene $\mathrm{CO}_{2}$ trends, Ruddiman discussed results based on simulations with GENESIS and DEMETER models (Foley, 1994) and PMIP intercomparison (Harrison et al., 1998). Here, we would like to add a word of caution that important atmosphere-biosphere feedbacks were not considered in these model examples. For subtropical deserts and semideserts, like North Africa, this limiting assumption leads to an underestimation of mid-Holocene precipitation changes (e.g. Claussen, 1997; Ganopolski et al., 1998). Hence we would like to draw the reader's attention to a study by Brovkin 
et al. (2002) in which we used the fully coupled atmosphere-ocean-vegetation model of intermediate complexity, CLIMBER-2 (Claussen et al., 1999; Petoukhov et al., 2000; Ganopolski et al., 2001), including interactive models of terrestrial and marine biogeochemistry. Our model results suggest that the largest changes of terrestrial carbon storage at $8000 \mathrm{yr} \mathrm{BP}$ (years before present) are associated with moistening of northern subtropical regions, while the increase in boreal forest biomass is smaller. Despite of a reduction in mid-Holocene atmospheric $\mathrm{CO}_{2}$ concentrations by 20 ppmv compared to pre-industrial values, the terrestrial biosphere in this interactive simulation contains about $90 \mathrm{PgC}$ more than seen in the pre-industrial control simulation. In the late Holocene, release of this carbon to the atmosphere could explain an increase in atmospheric $\mathrm{CO}_{2}$ concentration of some $10 \mathrm{ppmv}$. This value is too small in comparison with reconstructions of Holocene atmospheric $\mathrm{CO}_{2}$ concentration. Furthermore, simultaneous growth of peat storage in northern wetlands (Gajewski et al., 2001), which was not included in our model study, might have reduced or even reversed the trend in atmospheric $\mathrm{CO}_{2}$ concentrations. Hence natural changes in the terrestrial biosphere alone are presumably not sufficient to explain observed trends in Holocene atmospheric $\mathrm{CO}_{2}$ concentration - in this respect we agree with Ruddiman.

An aspect not included in this discussion are biogeophysical effects of land cover changes. If early Holocene land use would have resulted in a strong deforestation, then changes in albedo associated with deforestation in snow-covered regions should have led to a considerable cooling (e.g., Bonan et al., 1992) some 8000 years ago which tends to compensate or, at high latitudes, could overcompensate global warming due to emission of greenhouse gases by deforestation (Claussen et al., 2001). Hence Ruddiman's estimates of temperature changes arising from changes in land use should be revised.

Broecker et al. (1999) suggested that the Holocene increase in atmospheric $\mathrm{CO}_{2}$ concentration was caused by carbonate compensation in the ocean in response to the glacial-interglacial changes in the terrestrial carbon storage. Ruddiman rejects this explanation for two reasons. Firstly, he questions that the $\mathrm{CO}_{2}$ 'rebound' from $8000 \mathrm{yr}$ BP to pre-industrial conditions should have been four times the size of the early Holocene $\mathrm{CO}_{2}$ decrease. However accounting for the very long time scale of carbonate compensation, the $\mathrm{CO}_{2}$ growth might be caused by changes that started much earlier than $8000 \mathrm{yr}$ BP. This view is supported by wide-scale evidence of excessive accumulation of carbonate in deep ocean sediments during the Holocene (Milliman, 1993). In CLIMBER-2 simulations in which oceanic carbonate sedimentation was assumed to be constrained by changes in carbonate ion concentration as reported by Broecker et al. (1999), the model simulated a growth in atmospheric $\mathrm{CO}_{2}$ concentration in line with Taylor Dome data (Brovkin et al., 2002). In addition, excessive accumulation of carbonate presumably occurred due to the growth of coral reefs which were slowly adjusting to glacial-interglacial changes in sea level (Kleypas, 1997; Ridgwell et al., 2003). This process is independent of the $\mathrm{CO}_{2}$ 'rebound' at $8000 \mathrm{yr} \mathrm{BP}$. 
As a second reason for rejection of the oceanic hypothesis, Ruddiman argues that atmospheric $\mathrm{CO}_{2}$ variations between Holocene and previous interglacials differ. We cannot challenge this view, because we have not undertaken any simulation of the fully coupled climate system for previous interglacials. On the other hand, the Rudiman's hypothesis is also not free of problems. Two of its weaknesses inconsistency both with Holocene inventory of terrestrial biomass and with observed changes in $\delta^{13} \mathrm{C}$ - are discussed by Joos et al. (2004). We would like to point at a further problem related to Ruddiman's interpretation of paleo-climatic data. Ruddiman's hypothesis of (declining) atmospheric $\mathrm{CO}_{2}$ variations due to land use is based on the extrapolation of the observed $\mathrm{CO}_{2}$ trend during the early Holocene to the entire Holocene. Ruddiman did not explain why such decline should take place. However others (e.g. Indermühle et al., 1999; Broecker et al., 1999; Brovkin et al., 2002) have attributed the drop in atmospheric $\mathrm{CO}_{2}$ concentration during early Holocene to the re-growth of the terrestrial biomass after the retreat of ice sheets. Such process is limited in time and is likely to not last during the whole Holocene. Furthermore, if we consider the Eemian interglacial as an example of natural dynamics of atmospheric $\mathrm{CO}_{2}$ concentrations, then the pre-industrial Holocene $\mathrm{CO}_{2}$ concentration deviates from the 'natural' one by only $10 \mathrm{ppm}$, which completely changes the starting point of Ruddiman's discussion (see Figure 1b, thick full line and dashed line).

Meanwhile variations of atmospheric $\mathrm{CO}_{2}$ concentrations were recorded for the entire interglacial of MIS 11 (EPICA community member, 2004). It is clearly seen that atmospheric $\mathrm{CO}_{2}$ changes little or tends to increase during the first ten thousand years of MIS 11 (see figure 3 in EPICA community members 2004, the age scale is given in the supplementary information). Also the Vostok data (Petit et al., 1999) reveal a just slightly decreasing atmospheric $\mathrm{CO}_{2}$ concentration over a long period of time during MIS 11. Hence atmospheric $\mathrm{CO}_{2}$ variations during MIS 11 seem to be at variance with those recorded for the last three interglacial. This fact alone would refute any argumentation based on a similarity of greenhouse gas variation during all interglacials.

Regarding the question whether or not, anthropogenic land-cover change has led to an increase to atmospheric $\mathrm{CO}_{2}$ concentration, we agree to the statement that anthropogenic deforestation started as early as $8000 \mathrm{yr}$ ago or even earlier. However, we surmise that its consequence for the terrestrial carbon cycle is hard to evaluate based on available terrestrial proxies. Even for well-documented present-day conditions, the uncertainty in $\mathrm{CO}_{2}$ emissions associated with land use is uncomfortably high (Prentice et al., 2001). It is even more difficult to assess the anthropogenic influence on the atmospheric $\mathrm{CO}_{2}$ in the past, many thousand years ago. Besides, as pointed by Joos et al. (2004), a deforestation of the magnitude proposed by Ruddiman should be accompanied by much stronger changes in $\delta^{13} \mathrm{CO}_{2}$ than observed in the Taylor Dome record (Indermühle et al., 1999).

Hence we conclude that the case of atmospheric $\mathrm{CO}_{2}$ variations in the Holocene is still open; Ruddiman's hypothesis and reassessment of earlier theories is not free 


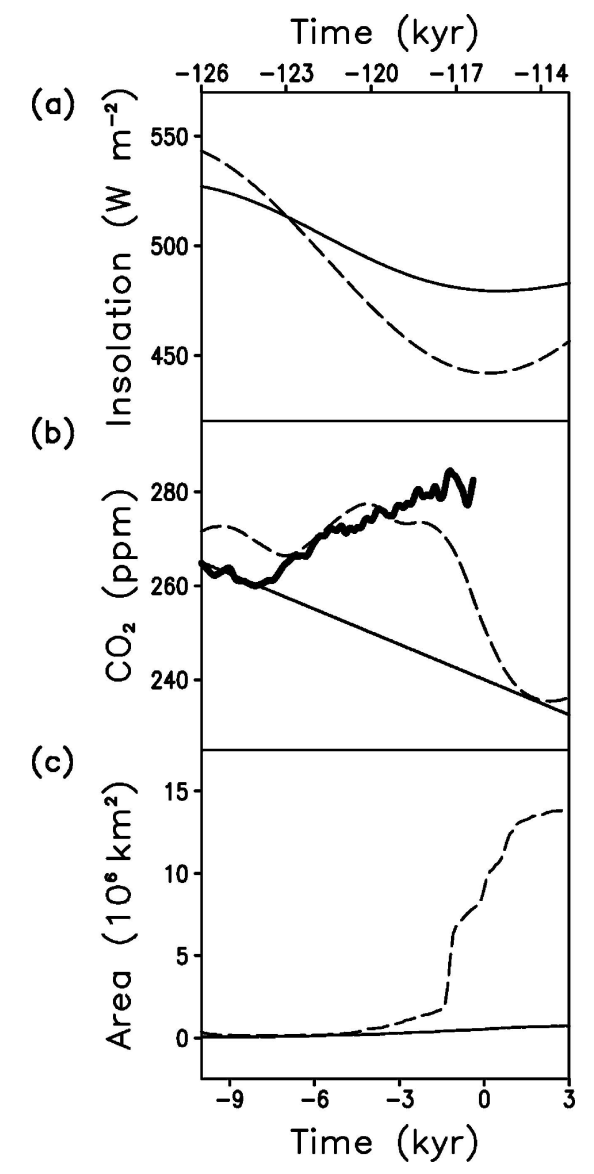

Figure 1. (a) Changes in maximum insolation at $65^{\circ} \mathrm{N}$ computed according to Berger (1978) for the Holocene (full line, corresponding time axis at the bottom of the figure) and for the Eemian/early Weichselian transition (dashed line, time axis at the top of the figure). (b) Atmospheric $\mathrm{CO}_{2}$ concentration for the Eemian and last glacial inception following Barnola et al. (1987) (dashed line, time axis at the top of the figure), atmospheric $\mathrm{CO}_{2}$ concentration for the last 10,000 year from Indermühle et al. (1999) (thick line, time axis at the bottom of the figure) and scenarios (full thin line) of a declining trend in atmospheric $\mathrm{CO}_{2}$ concentration for the Holocene. (c) Computed area of ice cover over the Northern Hemisphere (excluding changes in the Greenland ice sheet) for the last glacial inception (dashed line), and for the scenario of the hypothesized trend in atmospheric $\mathrm{CO}_{2}$ given in part (b, full thin line).

of problems, while recent modeling studies suggest that there is no need for a strong anthropogenic forcing to explain the Holocene $\mathrm{CO}_{2}$ trend.

\section{Glacial Inception in the Holocene: The Eemian is Not a Proper Analogue}

As a consequence of his assumption of an anthropogenically induced anomalous increase in Holocene atmospheric $\mathrm{CO}_{2}$ concentration, Ruddiman suggested that 
without anthropogenic pre-industrial land use, a glacial inception should have begun already 5000 years ago. This 'hindcast' is based on assessing the leads and lags between orbital parameters and ice volume reconstructed for the previous glacial cycles. We would like to question the validity of this approach for the following reasons. Some 5000 years ago, the atmospheric $\mathrm{CO}_{2}$ concentration was essentially the same as during the end of Eemian. Furthermore, maximum summer insolation at $65^{\circ} \mathrm{N}$ was the same as $1,23,000 \mathrm{yr}$ BP. Ruddiman argued that the previous glacial inception has started around this time. This assertion, however, is at variance with numerous well-dated coral data which indicate stable high stand of sea level at least until 1,20,000 yr BP, and, probably, several thousand years longer (e.g. Stirling et al., 1998). Already at 1,20,000 yr BP, summer insolation was lower than today by some $5 \%$. Ruddiman stated that the current summer insolation is the same as at $1,19,000 \mathrm{yr}$ BP. This apparent discrepancy arises because Ruddiman used July mean insolation at $60^{\circ} \mathrm{N}$ while we refer to maximum summer insolation. Although July mean insolation is frequently used in literature as a proxy for orbital forcing, it has little objective meaning because this value depends on the definition of calendar. A physically more plausible value in this respect is the maximum summer insolation. The latter value does not depend on the calendar definition. Moreover, work in progress (not illustrated here) suggests that the mass balance of inland ice reveals the highest correlation with maximum summer insolation at $65^{\circ} \mathrm{N}$. Maximum summer insolation leads July mean insolation by several thousand years.

To substantiate our statements we used the CLIMBER-2 model to perform two sensitivity experiments: (a) analysis of differences in climate caused by changes in insolation and in greenhouse gas concentrations, respectively, and (b) simulation of transient inland ice dynamics by using the fully coupled atmosphere-oceanvegetation-ice sheet model.

In the first experiment, we reduced atmospheric $\mathrm{CO}_{2}$ and $\mathrm{CH}_{4}$ concentrations from pre-industrial values by $40 \mathrm{ppmv}$ and $250 \mathrm{ppbv}$, respectively. Starting from pre-industrial climate, the model yields a summer cooling over the northern part of North America by $1-1.5^{\circ} \mathrm{C}$ (not illustrated here). A change in insolation due to a change in orbital parameters representative of today and of $116,000 \mathrm{yr} \mathrm{BP}$ - the time at which maximum summer insolation is smallest - respectively, results in a summer cooling of $3-4{ }^{\circ} \mathrm{C}$ in the same region. This clearly suggests that difference in orbital configuration between the last glacial inception and modern conditions seems to be much more important than a change in greenhouse gases of a magnitude suggested by Ruddiman.

In the second experiment, we tried to simulate a Holocene glacial inception. Before we continue to discuss the second sensitivity experiment, we briefly report on our experiments on the last glacial inception described in Calov et al. (2004). In that study of Calov et al. (2004), we used the same CLIMBER-2 model as used by Brovkin et al. (2002) except that the modules for terrestrial and marine biogeochemistry were switched off and atmospheric $\mathrm{CO}_{2}$ concentration was prescribed. Instead, a high-resolution, polythermal ice sheet model by Greve (1997) was implemented. 
This extended version of CLIMBER-2 was already used to simulate Heinrich events (Calov et al., 2002). The study by Calov et al. (2004) yielded two noteworthy results: Firstly, the model was able to successfully simulate the last glacial inception some 1,17,000 years ago. Secondly, the glacial inception appeared as a bifurcation in the climate system such that the area covered by snow increased rapidly within a few hundreds years (see Figure 1c), while the ice volume, and hence sea-level, changed more gradually. The main physical processes behind the fast glacial inception turned out to be the positive snow albedo feedback. The bifurcation parameter was maximum summer insolation in this case. Hence, the last glacial inception appeared once a certain threshold in maximum insolation was crossed.

Of course, selection of a single insolation parameter as trigger of glacial inception is ambiguous, as mentioned above. Summer insolation at northern latitudes is certainly not the only force that controls climatic variations. Berger et al. (1993) have shown that for a given latitude, the long-term variations of the mid-month insolation are out of phase by a sub-multiple of the precessional cycle. Only a geographically explicit model forced by daily and meridionally varying insolation, as done in CLIMBER-2, gives a more objective view of the problem. On the other hand, our model results corroborate that if one wants to choose an indicator, or "proxy", of a threshold value, then the maximum summer value, not the July mean value, of insolation appears to be good choice.

The successful simulation of the last glacial inception encouraged us to address the question whether orbital variations during the last ten and next three millennia could have initiated a glaciation in particular if atmospheric $\mathrm{CO}_{2}$ concentration would have decreased as suggested by Ruddiman. Therefore, we initialised the CLIMBER-2 model with an equilibrium climate computed for orbital configurations at $10,000 \mathrm{yr} \mathrm{BP}$. In the course of the Holocene simulation, the climate system model was driven by variations in orbital parameters according to Berger (1978) from which the globally and seasonally varying insolation was computed (Figure $1 \mathrm{a}$, full line, just shows the maximum insolation at $65^{\circ} \mathrm{N}$ ). As a scenario of atmospheric $\mathrm{CO}_{2}$ trend, we prescribed a linear decrease from mid-Holocene values of 265 ppmv to 240 ppmv for today (thin full line in Figure 1b). The change in area covered by ice is given in Figure 1c. Apparently, there is some increase in ice cover in the Holocene simulations, but a glacial inception as computed for the last glacial inception (dashed line in Figure 1c, the corresponding time axis is plotted at the top the figure) does not take place. Our explanation for this difference in model results is that Holocene variations in insolation at high northern latitudes are smaller than, and certainly above, those at the end of the Eemian (e.g. Figure 1a). Hence the critical threshold value of glacial inception was not yet crossed, and presumably will not be crossed for some 50,000 years. (The minima of maximum summer insolation at $65^{\circ} \mathrm{N}$ are $461 \mathrm{Wm}^{-2}$ at $398 \mathrm{ky} \mathrm{BP}, 458 \mathrm{Wm}^{-2}$ at $323 \mathrm{ky} \mathrm{BP}, 435 \mathrm{Wm}^{-2}$ at $231 \mathrm{ky} \mathrm{BP}, 442 \mathrm{Wm}^{-2}$ at $115 \mathrm{ky} \mathrm{BP}, 479 \mathrm{Wm}^{-2}$ at $0 \mathrm{ky} \mathrm{BP}, 482 \mathrm{Wm}^{-2}$ at $17 \mathrm{ky}$ AP (after present, i.e., after $1950 \mathrm{AD}$ ), $496 \mathrm{Wm}^{-2}$ at $36 \mathrm{ky} \mathrm{AP}$, and $469 \mathrm{Wm}^{-2}$ at 54 ky AP, e.g. Berger, 1978.) 
Our conclusion is corroborated by earlier studies by Loutre and Berger (2000) or Paillard (1998) who showed that orbital variations during the Holocene differ from those of the previous three interglacial-glacial transitions and who suggested that the present interglacial should last substantially longer than the previous three. Perhaps in this respect the Holocene could resemble the period of the Marine Isotope Stage 11, around 400,000 years ago when the eccentricity of the Earth orbit was very small, like today (e.g., Loutre and Berger, 2000).

In summary, our comment casts some doubt in using paleo-analogues for predicting climate variations. Albeit the search for paleo-analogues provides useful hints and is very helpful for creating new ideas, we suppose that a systems approach (Falkowski et al., 2000) is more likely to successfully describe the dynamics of the climate system. We assume that the climate system, including the carbon cycle, does not simply follow insolation such that one could speak of an "orbitally controlled variations in $\mathrm{CO}_{2}$ and $\mathrm{CH}_{4}$ concentrations" (Ruddiman, 2003). Instead our model studies suggest that the climate system should respond to insolation variations in a strongly non-linear manner - more like a system that reacts abruptly once a threshold in external forcing is crossed as suggested earlier (e.g. Paillard, 1998, 2001).

\section{Acknowledgments}

This work was partly funded by the BMBF (German Federal Ministry of Education and Research), DEKLIM (German Climate Research Program) project EEM (Climate change at the end of an interglacial). The authors thank the anonymous reviewers for constructive comments.

\section{References}

Barnola, J. M., Raynaud, D., Korotkevich, Y. S., and Lorius, C.: 1987, 'Vostok ice core provides 160,000-year record of atmospheric $\mathrm{CO}_{2}$ ', Nature 329, 408-414.

Berger, A.: 1978, 'Long-term variations of daily insolation and Quaternary climatic change,' J. Atmos. Sci. 35, 2362-2367.

Berger, A., Loutre, M. F., and Tricot, Ch.: 1993, 'Insolation and Earth's orbital periods', J. Geophys. Res. 98(D6), 10341-10362.

Bonan, G. B., Pollard, D., and Thompson, S. L.: 1992, 'Effects of boreal forest vegetation on global climate', Nature 359, 716-718.

Broecker, W. S., Clark, E., McCorkle, D. C., Peng, T.-H., Hajdas, I., and Bonani, G.: 1999, 'Evidence for a reduction in the carbonate ion content of the deep sea during the course of the Holocene,' Paleooceanography 14, 744-752.

Brovkin, V., Bendtsen, J., Claussen, M., Ganopolski, A., Kubatzki, C., Petoukhov, V., and Andreev, A.: 2002, 'Carbon cycle, vegetation and climate dynamics in the holocene: Experiments with the CLIMBER-2 Model', Global Biogeochem. Cycl. 16(4), 1139; doi:10.1029/2001GB001662.

Calov, R., Ganopolski, A., Petoukhov, V., Claussen, M., and Greve, R.: 2002, 'Large-scale instabilities of the Laurentide ice sheet simulated in a fully coupled climate-system model,' Geophys. Rev. Lett. 29(24), 2216; doi:10.1029/2002GL016078. 
Calov, R., Ganopolski, A., Petoukhov, V., Claussen, M., and Greve, R.: 2004, 'Transient simulation of the last glacial inception. Part I: Glacial inception as a bifurcation in the climate system,' Climate Dyn. (in press).

Claussen, M.: 1997, 'Modelling biogeophysical feedback in the African and Indian Monsoon region,' Climate Dyn. 13, 247-257.

Claussen, M., Brovkin, V., Ganopolski, A., Kubatzki, C., Petoukov, V., and Rahmstorf, S.: 1999, 'A new model for climate system analysis,' Environ. Model. Assess. 4, 209-216.

Claussen, M., Brovkin, V., Petoukhov, V., and Ganopolski, A.: 2001, 'Biogeophysical versus biogeochemical feedbacks of large-scale land-cover change,' Geophys. Rev. Lett. 26(6), 10111014.

Crutzen, P. I. and Stoermer, E. F.: 2000, 'The Anthropocene', IGBP Newsletter 41, 12.

EPICA community members: 2004, 'Eight glacial cycles from an Antarctic ice core,' Nature 429, 623-628.

Falkowski, P., Scholes, P. J., Boyle, E., Canadell, J., Canfield, D., Elser, J., Gruber, N., Hibbard, K., Högberg, P., Linder, S., Mackenzie, F. T., Moore, B., III, Pedersen, T., Rosenthal, Y., Seitzinger, S., Smetacek, V., and Steffen, W.: 2000, 'The global carbon cycle: A test of our knowledge of Earth as a system,' Science 290, 291-296.

Foley, J.: 1994, 'The sensitivity of the terrestrial biosphere to climatic change: A simulation of the middle Holocene,' Global Biogeochem. Cycl. 8, 505-525.

Gajewski, K., Viau, A., Sawada, M., Atkinson, D., and Wilson, S.: 2001, 'Sphagnum peatland distribution in North America and Eurasia during the past 21,000 years,' Global Biogeochem. Cycl. 15, 297-310.

Ganopolski, A., Kubatzki, C., Claussen, M., Brovkin, V., and Petoukhov, V.: 1998, 'The influence of vegetation-atmosphere-ocean interaction on climate during the mid-Holocene,'Science 280, 1916-1919.

Ganopolski, A., Petoukhov, V., Rahmstorf, S., Brovkin, V., Claussen, M., Eliseev, A., and Kubatzki, C., 2001: 'CLIMBER-2: A climate system model of intermediate complexity. Part II: Model sensitivity', Climate Dyn. 17, 735-751.

Greve, R.: 1997, 'A continuum-mechanical formulation for shallow polythermal ice sheets', Phil. Trans. R. Soc. Lond. A 355, 921-974

Harrison, S. P., Jolly, D., Laarif, F., Abe-Ouchi, A., Dong, B., Herterich, K., Hewitt, C., Joussaume, S., Kutzbach, J. E., Mitchell, J., de Noblet, N., and Valdes, P.: 1998, 'Intercomparison of simulated global vegetation distributions in response to $6 \mathrm{Kyr}$ BP orbital forcing', J. Climate 11, 2721.

Indermühle, A., Stocker, T. F., Joos, F., Fischer, H., Smith, H. J., Wahlen, M., Deck, B., Mastroianni, D., Tschumi, J., Blunier, T., Meyer, R., and Stauffer, B.: 1999, 'Holocene carbon cycle dynamics based on $\mathrm{CO}_{2}$ trapped in ice at Taylor Dome, Antarctica', Nature 398, 121-126.

Joos, F., Gerber, S., and Prentice, I. C.: 2004, 'Transient simulations of Holocene atmospheric carbon dioxide and terrestrial carbon since the Last Glacial Maximum', Global Biogeochem. Cycl. 18(2), GB2002.

Kleypas, J. A.: 1997, 'Modeled estimates of global reef habitat and carbonate production since the last glacial maximum', Paleoceanography 12, 533-545.

Loutre, M. F. and Berger, A.: 2000, 'Future climatic changes: Are we entering an exceptionally long interglacial?', Climatic Change 46, 61-90.

Milliman, J. D.: 1993, 'Production and accumulation of calcium carbonate in the ocean: Budget of a nonsteady state', Global Biogeochem. Cycl. 7, 927-957.

Paillard, D.: 1998, 'The timing of Pleistocene glaciations from a simple multiple-state climate model', Nature 391, 378-381.

Paillard, D.: 2001, 'Glacial cycles: Towards a new paradigm', Rev. Geophys. 39(3), 325-346.

Petit, J. R., Jouzel, J., Raynaud, D., Barkov, N. I., Barnola, J. -M., Basile, I., Bender, M., Chappellaz, J., Davis, M., Delaygue, G., Delmotte, M., Kotlyakov, V. M., Legrand, M., Lipenkov, V. Y., Lorius, 
C., Pépin, L., Ritz, C., Saltzman, B., and Stievenard, M.: 1999, 'Climate and atmospheric history of the past 420,000 years from the Vostol ice core, Antarctica', Nature 399, 429-436.

Petoukhov, V., Ganopolski, A., Brovkin, V., Claussen, M., Eliseev, A., Kubatzki, C., and Rahmstorf, S.: 2000, 'CLIMBER-2: A climate system model of intermediate complexity. Part I: Model description and performance for present climate', Climate Dyn. 16(1), 1-17.

Prentice, I. C., Farquhar, G. D., Fasham, M. J. R., Goulden, M. L., Heimann, M., Jaramillo, V. J., Kheshgi, H. S., Le Quéré, C., Scholes, R. J., and Wallace, D. W. R.: 2001, 'The carbon cycle and atmospheric carbon dioxide', in Houghton, J. T., Ding, Y., Griggs, D. J., Noguer, M., van der Linden, P., Dai, X., Maskell, K. and Johnson, C. I. (eds.): 2001, Climate Change 2001: The Scientific Basis, Contribution of Working Group I to the Third Assessment Report of the Intergovernmental Panel on Climate Change, Cambridge University Press, $881 \mathrm{pp}$.

Ridgwell, A. J., Watson, A. J., Maslin, M. A., and Kaplan, J. O.: 2003, 'Implications of coral reef buildup for the controls on atmospheric $\mathrm{CO}_{2}$ since the Last Glacial Maximum', Paleoceanography 18, 1083.

Ruddiman, W. F.: 2003, 'The anthropocene greenhouse era began thousands of years ago', Clim. Change 61, 261-293.

Stirling, C. H., Esat, T. M., Lambeck, K., and McCulloch, M. T.: 1998, 'Timing and duration of the last Interglacial: Evidence for a restricted interval of widespread coral reef growth,' Earth Planet. Sci. Lett. 135, 115-130.

(Received 27 May 2004; accepted 1 December 2004) 